\title{
The Representational Politics of Oscar Winning Movies of Obama Period
}

\author{
Julia G \\ Post Graduate Student \\ Journalism and Mass Communication \\ Central University of Punjab \\ Bathinda, Punjab , India \\ jeweljulia460@gmail.com
}

Abstract

This paper attempts to focus on Academy Awards belonging to a particular timeline, specifically during the administration Council of America's 44th President Barack Obama ( 20 January 2009 to 20 January 2017). It concentrates on the selection of movies and its themes that has been reflected in three wider sections such as war, black and LGBTQ movies. The primary objective of this particular paper is to discover the obscured and parallel politics that usher the process of selection in Academy. This paper tries to exemplify the actuality that in selecting foremost movies in the Academy entertain superior authority and their governance and also how the assessment of movies are culturally and politically biased. All discussed movies are the findings of chief objective and are primary sources that fundamentally appease its argument that selection of Oscar winning movies are culturally and politically biased.

Keywords: War Black LGBTQ Movies, Orientalism, Hegemony, Queer Introduction

The Academy Awards, universally familiar as Oscars, are awards of artistic and technical merit in the film industry. It is given by the Academy of Motion Pictures Art and 
Sciences (AMPAS) annually, and is estimated through voting. The Academy was created in 1927 and the first Oscars were declared in 1929.

Everything on this running globe is within the tangled motion of power politics. Majorityfavours people with power under certain rules. Movies also have got the tendency to channelizetheir way of portraying in favour of the present ruling authority. "Nearly every film could be constructed as political in some fashion: politics affects every human endeavour and it is possible to interpret a film as commenting on any number of issues" says Ben Zauzmer in "IfYou Think the Oscars Have Gotten More Political, Here's Why You're Right".

In his article he comments on five points out of which a film had to meet at least one tobe considered as political.

1. It could show an attempt to gain political power

2. It could portray a debate over how to govern

3. It could cover political events of past or the present

4. It could explore conflict between sovereign powers

5. It could very plainly be making a statement about an issue

When we cross check the history of Oscar, winning movies largely record political inclination in its themes and philosophical contents. It is an unquestioned fact that over 90 years of Oscar history, salient appraisal for movies goes for films under the banner of American creation. It is ironic with the context that the Academy usually considers world competing movies in order to select the preeminent out of it. Exceptions are 2020 best picture Parasite and The Artist of 2012. Even the 2021 Oscar has shown great diversity in considering awards.

However, the majority of nominations and recognitions of mainstream awards always cater to the interest of white authority. A big picture of this diplomatic affair can be comprehended when we inspect the rules for voting Oscar winning best movies. Third and 
fourth official criteria for selection of movies states that "the movie must open in a commercial theatre, for paid admission in Los Angeles county between January 1st and midnight December 31st and run for 7 consecutive days at least three screenings daily (one of which needs to be between 6:00 p.m. and 10:00 p.m) be sufficiently advertised in Los Angeles media" (McKittrick),

Second ironic factor is that the selection is done by the voting system in which decisions will be taken by Academy voting members where the majority are the representatives of the United States. This specific study focus on War, Black and LGBTQ movies of Obama's counsel together with the application of theories like orientalism, postcolonial ideology of hegemony and queer theory.

War Movies

Considering Barack Obama's term and Oscar winning war movies which have emergedimplies a viewing of the US defence forces through a spotless glass. Most of them have gained direct recognition from the Academy. Some of them are The Hurt Locker (2008), Zero Dark Thirty(2012), American Sniper(2014), Inglorious Bastards (2009), War Horse (2011), The Imitation Game(2014).

\section{The Hurt Locker}

This pro-war film is about the story of Sergeant William James as a dedicated bomb defuser who unabashedly celebrates American foreign policy in an alien land. The movie is directed by Kathryn Bigelow, the first woman to win an Academy Award for Best Director and for best picture.

It was also selected for best original screenplay and sound mixing. "She narrates the story of the US Bomb Squad in Iraq. This movie specifically depicts the contested US presence in Iraq" (Tasker 59). In Foreign Affairs Obama worked to improve the international image of the United States. He also vowed to work towards the elimination of nuclear 
weapons. A milestone in Obama's Foreign Policy was the end of the Iraq war by adopting the foreign policy The Joint Comprehensive Plan Of Action ( JCPOA). He promoted the US Army to go outside the countryfor mainstream peace and order.

No one else in the movie likes the place Baghdad except the hero. Though other characters are accurate in what they are doing, they are not stubborn and mentally strong like James who is daring enough to die with intense passion for the warfront. The comment made by other soldiers on William is " he is a Rowdy boy, he is reckless" (The Hurt Locker, Bigelow, 2008). He holds a record of disarming 873 bombs. The choice between home and warfront is nota random matter for James. He always opted warfront first, what he says to his little child is also relevant in this perspective. "As you get older there are few things you really love and by the time you get to my age may be it's only one or two things with me, I think it's only one" ( the choice of warfront, from the movie).

Baghdad in the movie is introduced to the audience as a war strewed land.The construction of the enemy in the movie is mere physical and more psychological. Robert Sklar argues that the Iraqis in the film are represented in prejudicial terms. Most Iraqis are seen at a distance (often through the sights or of a rifle) and in a small number of sequences where thecharacters come into focus.

Robert Kelly criticize the film by saying that

" the film is trying to capture the war from 'American soldiers point of view', especially the film is not really about Iraq but about contemporary US warfighter. The average G.I (G.I. are initials used to describe the soldiers of the United States Army and airmen of the United States Air Forces and also for general items of their equipment ) there clearly doesn't speak Arabic or know the culture, so I actually found the 'othering of Iraq' is as a powerful narrative device.

Most of the situations in the movie, it is very evident that the tensions and mental 
strainsthrough which the US Combat team goes through is immense. James is presented in a fairly conventional heroic term but he is also shown to be suffering from PTSD, he is addicted to war, disobeys orders and prone to lapses of judgement. ( The Hurt Locker Mapping)

The title of the movie denotes this idea of pain and discomfort that the US Army had gone through. "Hurt Locker is a slang term for a place of deep pain and discomfort, to be put inHurt Locker signifies that something profoundly troubling or painful has happened to you" (Wikitionary).

Thus this movie has clearly illustrated the tension of the US Army on the desert land of Iraq. Movie climax reinforces the idea of a true soldier as one who is always at the warfront by showcasing the choice made by Sergeant William James to be at the warfront for the sake of his country.

\section{American Sniper}

American Sniper is a 2014 biographical war drama which unveils the personal life of an extraordinary individual torn between family and duty. It has received several Academy award nominations together with winning best sound editing in 2015 .

Chris Kyle is a sniper under America's SEAL (The United States Navy Sea Air and Land teams) commonly known as Navy SEALS are US Navy primary operation force and the component of the naval special warfare command.

Akin to Sergeant William James in Hurt Locker Kyle is also a wild war man. But he creates space and time for his family. The initial conversation between Kyle (Bradley Cooper)and Taya (Sienna Miller) reveals how passionate and patriotic he is.

" I'd lay down my life for my country, it is the greatest country on earth. I'd do everything I canprotect it "(American Sniper, Eastwood,2014)

War, family together with the psychological trauma of the hero become the most 
discussed themes of the movie. Being patriotic and devoted to his country he sets aside the major part of his life to be in the war zone. Soldiers call him 'the Legend', people call him 'Hero' but he knowingly or unknowingly carries guilt of killing people. He develops PTSD (Post Traumatic Stress Disorder) which causes him to be increasingly disconnected from his family life, having become absent minded and constantly slips back to the evils of war. Though the Navy has credited him with 160 kills, the thought of lives of soldiers he couldn't save haunts him ever after quitting his job.

The discourse of movie is Eurocentric which represent Arab Muslim Middle Eastern communities 'enemy'. " with the use of eurocentric discourse, common stereotypes and trops of empire, American Sniper delivered a racist portrayal of Arab and Muslim populations hypnotizing scenes of American patriotism" ( Ready).

Applying the theory of Orientalism by Edward Said who was one of the most important cultural figures of the late 20th century. In his 1978 book Orientalism Said made the influential argument that the scholarly writings from America and Europe presented an inaccurate, misleading and stereotyped cultural representation of the East. Said believed this biased perception hindered a true understanding of Middle Eastern and East Asian culture. He argued when Western Scholars studied Eastern culture they couldn't understand it because of its deviant nature from their own culture. So they portrayed East as exotic, enigmatic. "Orientalism," as defined by Edward Said, is the Western attitude that views Eastern societies as exotic, primitive, and inferior. A way of seeing that imagines, emphasizes, exaggerates and distorts differences of Arab peoples and cultures as compared to that of Europe and the U.S. It often involves seeing Arab culture as exotic, backward, uncivilized, and at times dangerous.

The word 'savages' pop up several times in the film, the crude language of the film which dehumanizes enemy "a lot of people myself included called the enemy 'savages' I only 
wish I had killed more not for bragging rights but because I believe the world is better place without savages out there taking American lives" (epithet used by Chris Kyle to describe Arabs on the wrong side of his gun scope). Kyle joined SEALS because he wanted to protect the US from foreign savages. There are no innocent Iraqi depicted in the film, they are either murderous insurgents or collaborators.

Even though violence is portrayed and unlike the previous movie the emotional aftermath of murder is shown. Rational strife confronted by the soldier is evidently recorded. The intention of a rescuing capability of a whole country is depicted through the 'Saviour image' of Kyle. Thus the movie can be examined for its celebration of American policy of extrication that caters to nationalism.

Not only these two movies, other movies like Lincoln (2012), Argo (2012), Hacksaw Ridge (2016) and documentaries like Restrepe ( 2010 by Sebastian Junger and Tim Hethreington) Redacted (2007 by Brian De Palma) which have garnered heavy praise seem tosupply the same message : The United States is a powerful force of Social Justice.

Common thread through which these movies are connected to Obama politics is Patriotism. Obama politics always had a hope and assurance of 'One Nation'. Also these moviesdepicted US military defense forces and their tireless passion towards their country in an empyreal elegance. When we look back to Oscar history most of the war movies are with the repeated theme of patriotism but particularly in Obama period war movies centralised in true events that were associated with poignant political movements. Also the representation politics in 'othering', elements of self-sacrifice, the reputation of the Army highlights the uprightness ofthe US defence force.

\section{BLACK MOVIES}

The conception of 'Oscar only to white' was profoundly entrenched in the psyche of 
global cinema. Although each year an anomalous performance obtained appreciation from the Academy, the lion's share of predilections goes for movies under white production. "In Academy's 89 years of history only 39 Oscars have given to black actors and actresses" (Yolanda Sangweni) Regarding Oscar top scoring black movies during the incumbency of Obama, award culture pinpoints a deviant cult in certifying movies. Quite a few black movies had been released and most of them attained Academy appraisal directly. Portrayal of blacks from different perspectives, their involvement in vivid arenas and repercussions of \#Oscarisso white has inflamed the growing attendance of African American movies in Hollywood, or in other words, somehow this has temporarily put an end to the racial tension that existed in Hollywood. Apart from the mainstream awards, the approval of black talents invarious nuanced sectors of the film fields has also become prevalent.

" First I would like to thank the academy for showing that it can be about the performance and not the politics." Mo'nique, the black actress's words after receiving the Academy award for best supporting actress reminds us of this age old disparity.

Yet another reminder is " Hey, I'm here at the Academy awards, known as the white people choice of works, you realize if they nominated host, I don't even get this job"

( Chris Rock at the opening Ceremony of Academy Awards in the year 2016. He was thesecond black host in Academy after Whoopi Goldberg)

Movies that need special mention here are Moonlight (2016), The Help (2011), Fences (2016), Hidden Figures (2016), Fruitvale Station (2013), Mandela : Long Walk to Freedom (2014), The Butler (2013). The same color wave is reflected in Animated movies too. Examplesare Moana (2016) and Kubo and the Two Strings (2016).

Paying particular attention to this context, this paper examines movies like 12 Years aSlave, best picture of 2014 and Django unchained of 2013.

12 Years a Slave 
This film is the adaptation of the 1853 slave memoir by Solomon Northup. It became a highly prestigious movie of 2014 Academy Awards by receiving prizes for best picture, best supporting actress and adapted screenplay. Altogether the movie is nominated for 9 Academy awards. The director of the film Steve McQueen thus became the first Black British director andproducer to win the Academy Award.

The subject matter of the movie is slavery and silent survival strive for deliverance during 1800 through the realistic portrayal of violence, trauma and through the image of tortured slave body. Solomon Northup (Chiwetel Ejiofor), a free man leading the life of dignity in Saratoga, Newyork as a professional violinist, gets into trouble when he meets with Mr Brown and Hamilton. These two refined men delude him and makes him surrender to slavery. Subsequently white slave masters trade him as a slave with the brand name of 'Platt' to a plantation owner called Ford (Benedict Cumberbatch). Though there he acquires esteem in the eyes of Ford, bad encounter with chief engineer and egoistical confrontation between both of them eventuate in selling Solomon to an alternative slave owner. In contrast to Ford, new slave owner Edwid Epp ( Michael Fassbender) misbehaves with everyone based on his priority and causes endless work and distress to his servants. He is ruthless and treats them as if he is a despotic. He emotionally and violently torments his workers and tries to find sadistic pleasure out of it. In one of the movie scenes he reads out false scripture to slaves and preoccupies his state of mind.

" servant which knew his Lord's will and prepared not himself neither to do according tohis will shall be beaten with many straps, now this many straps signifies a Great Mini, 40, 100,150 lashes "(12 Years A Slave, McQueen, 2014).

His commanding nature indicates the postcolonial ideology of 'hegemony'. Fundamentally, hegemony is the power of the ruling class to convince other classes that their interests are the interests of all, which are presented as common interest. Hegemony is 
important because the capacity to influence the thought of the colonized is by far the most sustained and potent operation of imperial power in colonized regions. For Gramsci, hegemony was a form of control exercised primarily through a society's superstructure, as opposed to its base or social relations of production of a predominately economiccharacter. (Mastroianni)

For Gramsci the ruling class used hegemonic ideas to gain domination over the subjugated classes. Gramsci argued that the ruling classes achieve domination by manipulating language, culture, morality and common sense. Throughout history the term hegemony was used to describe physical and political control. In cultural hegemony, dominant groups use their culture to legitimize their dominance. It is the fundamental idea that the power is not just exercised through physical force but is also reinforced through the story that we tell and images that we make.

Throughout the movie the master is presented as a man dominated by his animal instinct. The depiction of violence and torturing of slave bodies, stripping of identity and abusing scenes taken against enslaved African Americans are numerous in detail. McQueen attributes the need for the violence to understand not just physical abuse elements of slavery but the psychological as well.

The movie can be evaluated from the spectrum of enduring determination and hope ofSolomon Northup and his saga of survival through the act of perseverance.

\section{Django Unchained}

The protagonist of the film is a black slave Django (Jamie foxx) who becomes a free man with the help of a German doctor Shultz (christoph waltz) Afterwards the film follows the voyage of Django as a free man and his precarious journey as a bounty hunter. Gradually he became intent on delivering his sweetheart Broomhilda (Kerry Washington). Thus both the doctor and Django ended up meeting Calvin Candie (Leonardo DiCaprio), a wealthy 
established plantation owner. Ensuing events lead to a brutal massacre of white masters in the movie and itends by demonstrating the liberty achieved by Django and Broomhilda.

This film has gathered nominations for best picture and best cinematography besides bagging Academy Award for Best original screenplay and best supporting actor in the year of 2013.

Black masculinity shown in the movie goes to the era of blaxploitation (the exploitation of black people, especially with regard to stereotyped roles in films) films. Tarantino, the director of the movie, makes the character Django the hero of his story and gives him many attributes of the white people. Thus Django Unchained can definitely be called a western movie in which white Hero doesn't emerge and revenge takes a huge role throughout the movie.

"Jamie foxx character Django represents the black hero who speaks AfricanAmerican Vernacular English (AAVE). Tarantino expresses power through language in this character andDjango's AAVE dialect is represented as equal in authority to the dialects of the film's white character" ( Clouse).

Explaining of slavery and depiction of violence concurrently emerges in the story plot.

Extermination scenes from the movie validate the gradual uprising of an unstoppable hero from amere slave. The violence of the movie can be interpreted in two ways, one as the over exaggeration of killing scenes and other as the unbashed celebration of deliverance from slavery,the title of the movie itself herald the hint of this.

Above discussed movies explores freedom from shackles of slavery and racial tensions. This mode of orientation can be located in different movies of the Obama period. Some movies discuss the themes of eradication of slavery through the portrayal of life of slavery abolitionist activists like Martin Luther King, Nelson Mandela. Song from the movie 
Zolma which shows the historic struggle of Martin Luther King for securing voting rights to all people won the bestoriginal song of the year 2015 .

Obama as the first African American President in the history of America has worked to improve the lives of African Americans broadly. The effect of his administration that favoured colored community has reflected in various societal sectors including education, employment, health, law and justice.

In order to encapsulate, Oscars of these years have embraced diversity in accepting movies of black community. Reverberation for emancipation from slavery and liberty from racialconflicts reciprocated in general in movies.

\section{Lgbtq Movies}

" As long as I have the privilege of being your president I promise you, you all deserve a friend and the White House you will have a fellow African for America where no matter what you look like or where you come from who you love you can dream big dreams anddream as openly as you want " (Obama)

In 2011, President Obama declared DOMA (The Defense Marriage Act) unconstitutional.

New York legalizes same-sex marriage. Ahead of President Obama's widely telegraphed "evolution" on same sex marriage, Vice President Joe Biden announced that he was "absolutely comfortable" with same sex marriage. Wisconsin's Tammy Baldwin became the first LGBTQ person ever elected to the US senate in November 2012. Laverne Cox, best known for her role in the hit Netflix series "Orange Is the New Black" became the first transgender person to appear onthe cover of TIME magazine in June 2014. A month later she became the first Trans person to benominated for an Emmy. In 2015 Supreme Court legalized gay marriage.

Obama's belief was to treat people equally, render them equal protection under the 
law against all discrimination based on their sexual orientation though he respected religious and cultural concerns. His thought was about the state's operation in relation to people. Since taking office President and his administration have made historical strides to expand opportunities, equality and justice for all Americans including lesbian gay bisexual and transgender Americans, from major legislative achievements to historical Court victories to important policy changes the President has fought to promote the equal rights of all Americans no matter who they are or whothey love. He legalised same sex marriage across the nation and included gays openly in the forces. He has built stonewall a National monument for LGBT community in addition to this he contributed special medical aids to queer people.

It is in this contest the two movies winning Academy Award going to be discussed together with the application of the queer theory.

Prepending queer theory in this frame of referance.

The goal of this theory which emerged during the 1990's is to change the monolithic thoughts, taxonomies and social norms about sexuality. Queer theory seeks to debunk common misconceptions about sexuality and gender. It seeks to find the cultural and political space for all genders where homosexual is no longer considered as perverted immoral or 'sick 'other of heterosexuality. Basically this theory problematizes the binaries of sexual politics and argues that these binaries such as male-female, masculine-feminine, hetrosexual- homosexual establish a hierarchy and as a consequence reinforce the notion of minorities as abnormal and inferior. It consider the performativity of which was coined by Judith Butler one of the primary founding theorists of queer theory. Essentially performity means gender is not what we are, gender is whatwe do. There is no authentic performance of gender, all gender is an imitation or a copy. Third tenet of queer theory is that it seeks to dismantle the idea of 'hetronormativity' (the idea of normal or natural form of attraction, 
relationship is between man and woman).

Moonlight

Moonlight by Barry Jenkins became the first film with an all-black cast, the first LGBTQ film to win Oscar best picture. Joi MacMilon became the first black woman to be nominated for an editing Oscar and Marhershalal Ali became the first Muslim to win an actingOscar.

The film develops by presenting three life stages of the protagonist. Little, Chiron and Black respectively to adolescence youth and early adulthood. These phases prospect the perplexity of the protagonist with his conflicted sexuality. Society in which Little as a small boylived alienated him because of his drug addicted mother. However he manages to meet Juan whoteaches him how to swim and advises him to make his own path in his life. Second phase of his life is about his revelation to his own sexual orientation with the help of his classmate Kevin.

The indication of intimacy that shoot up between Kevin and Little is captured in the movie in a quarreling scene between two. He gradually transforms into a reckless boy and ends up in Juvenile hall. And then the adult phase called Black can be considered as a reconcile phase where he patches up with his mother and reunites with Kevin. Milk

This movie won Academy Awards for Best Actor and best original screenplay in 2009 and is directed by Gus Van Sant who is one of the few openly gay directors in Hollywood. This biographical film is based on the life of gay right activist and politician Harvey milk who was the first elected gay person to the public office in California as a member of the San Francisco Boardof supervisors. In 2002 Harvey Milk was called the most famous and most significantly open LGBT official ever elected in the United States.

The film commence by screening several news cuttings of police brutality against gay community and time period captured is of 1970s. On his 40th birthday Milk (Sean Penn) 
who was an insurance man met with the young vibrant man Scott (James Franco) and both of themmade the decision to live together and thus ended up settling down in San Francisco in 1972. Together they start a camera shop which gradually becomes a safe haven to all homosexuals inthe city. When the police force maltreated gay community Harvey stood out for his communityby announcing his candidacy for San Francisco city supervisor.

Amidst of life threats and lack of support Milk was destined to never give up and in the long run he wins district election of 1977 and publishes city's first gay right law, conducts gay freedom parade and public debates in order to establish the normality of a LGBTQ community. Envious of growing popularity and public acceptance of Milk, Dan White the City Supervisor assassinates him.

Although movies of LGBTQ contents during the ministry of Obama were handful in number, nearly all of them were rewarded from the Academy like Carol, Dallas Buyers Club, Danish Girl. The acceptance and recognition of such movies shows the attitude of societal changing and deviating norms. Also the fact is clear that movies are digressive according to thepolitical influctions and favours. All these movies echoes the voice of queer community and thewidespread presence of political functioning.

Conclusion

This paper pinpoints the idea of representing America as a 'nation', their political agendas and philosophical beliefs in internationally acclaimed movies. How war related movies portraying 'American Nationalism' and propagates the essential idea of patriotism. All such movies which obtained Academy appreciation put emphasis on the flawless representation of the US defense team. Furthermore the representation of blacks in mainstream movies and the attitude adopted by the Academy towards such movies in general which addressed issues of racism. Finally about Oscar winning LGBTQ movies.

The political inclinations of above discussed movies are significant when we collate 
it with the political functionings of Obama's administration. He tried to maintain mainstream peaceby sending out US army troops out of the country and officially put an end to the Iraq war by declaring withdrawal of US troops from Iraq. He had worked immensely for the overall welfare of black community. Provided special attention for the upliftment of African Americans in all sectors. Also Obama becomes the first president to support same-sex marriage. He signs an executive order protecting LGBT employees working for government contractors. In 2014, this administration interprets the Civil Rights Act as supportive of LGBT rights and he becomes the first president to use the word 'transgender' in a State of the Union address.

Here the points suggested by Ben Zausmer in his article out of which a film had to meetat least one to be considered as political is relevant.

1. It could show an attempt to gain political power

2. It could portray a debate over how to govern

3. It could cover political events of past or the present

4. It could explore conflict between sovereign power

5. It could very plainly be making a statement about an issue

Although Oscars consider movies from all countries, the elite nominations of best picture and best director always focus on Hollywood movies. The recognition of movies at the Academy Award is biased by the political party in power as well as the general political view of a majority group. Tracing back the best pictures of Oscar from 2010 to 2017 The Artist is the only movie that is under the French Company production that has won best picture award. Oscars of 2020have also enthusiastically welcomed the movie under Korean production (Parasite). Parasitemade Oscar history as the first film not in English to win best picture. The comment made by Donald Trump on its selection is contemptuous and ironic.

" How bad were Academy Award this year ? the winner is a movie from South 
Korea, what the hell was that all about. We got enough problems with South Korea with trade and on topof it they give them best movie of the year" ( Trump)

Hence this paper has focussed to well define the universal propagation of American agendas through Oscar winning movies within a particular time period. Movies play a great role in moulding one's understanding and opinions about worldview and leads to an internalization of total human conception. When they are credited with all encompassing ratification, it generates hidden superior vital forces to general human inception of thought. All discussed movies of this paper are the findings of chief objective and that fundamentally appease its argument that selection of Oscar winning movies are culturally and politically biased. 


\section{Works Cited}

Primary Sources

Bigelow, Kathyrn. " The Hurt Locker". Voltage Pictures, 4 Sep. 2008.

Eastwood, Clint. " American Sniper". Village RoadShow Pictures, 11 Nov. 2014.

Jenkins, Barry. " Moonlight". Plan B Entertainment, 2 Sep. 2016.

Steve, McQueen. " 12 Years a Slave". Regency Enterprises, 30 Aug. 2013

Sant, Van. Gus. " Milk". Axon Films, 28 Oct. 2008.

Secondary Sources

Affleck, Ben. " Argo". GK Films, 31 Aug 2012.

"African-American representation in Hollywood". https://en.m.wikipedia.org/wiki/AfricanAmerican_representation_in_Hollywood Retrieved 25 Feb 2020.

$\begin{array}{llllll}\text { Barack Obama and his administration, } & \text { December } & 12 & 2008\end{array}$ https://web.archive.org/web/20091026043047/http://www.whitehouse.gov/administrat ion/president-obama . Accessed 17 June 2019.

Brown, M. Carolyn. " Reflecting on Barack Obama's Accomplishments in Tumultuous Times ". Black Enterprise, 19 June 2018, https://www.blackenterprise.com/presidentobamas-positive-track-record-for-helping-afr ican-americans/ . Accessed 07 Dec 2019.

Burgoyne, Robert. " Embodiment in the war film: Paradise Now and The Hurt Locker ". Taylor and Francis Online Journals, 07 Sep 2013, https://www.tandfonline.com/doi/abs/10.1386/jwcs.5.1.7_1 . Accessed 16 Nov 2019.

Chadwick, Justin. "Mandela: Long Walk to Freedom". Videovision Entertainment, 7 Sep 2013. Clements, Ron. "Moana". Walt Disney Pictures, 14 Nov 2016.

Clouse, Lindsey. "Django Unbleached: The Languages of Power and Authenticity in Mainstream Film". Taylor and Francis, 18 Nov 2019, 
https://www.tandfonline.com/doi/abs/10.1080/01956051.2018.1562415 .Retrieved 19 Mar 2020.

Coogler, Ryan. "Fruitvale Station". Significant Productions, 19 Jan 2013. Corliss,Richard. " The Hurt Locker: A Near-Perfect War Film ". Time, 04 Sep 2008, http://content.time.com/time/arts/article/0,8599,1838615,00.html . Accessed 28 Jan 2020.

Daniels, Lee. "The Butler".Laura Ziskin Productions, 16 Aug 2013.

"Does 'Django Unchained' get the history of slavery right?". The Grio, 26 Dec 2012, https://thegrio.com/2012/12/26/does-django-unchained-get-the-history-of-slaveryright/ . Retrieved 25 Mar 2020.

"Edward Said- An Introduction to Orientalism". Youtube, uploaded by BBC Ideas, 30 April 2019, https://youtu.be/ZST6qnRR1mY .Obtained 25 Feb 2020.

Fitzsimons, Tim. " A very LGBTQ decade: Gay marriage, trans rights and a 'rainbow wave' ". NBC news, 29 Dec 2019, https://www.nbcnews.com/feature/nbc-out/very-lgbtqdecade-gay-marriage-trans-rights-rainbow-wave-n1107901 . Accessed 1 Mar 2020.

Friedkin, William. "The Boys in the Band". Cinema Center Films, 17 Mar 1970. Gibson, Mel. "Hacksaw Ridge". Summit Entertainment, 4 Sep 2016.

Haynes, Todd. "Carol". Number 9 Films, 17 May 2015.

Hazanavicius, Michel. "The Artist". La Petite Reine,2011 Hoper, Tom. "Danish Girl". Artemis Productions, 5 Sep.2015.

Hornaday, Ann. "Has there been an 'Obama effect' in Hollywood?". The Washington Post, 02 Sep 2016, https://www.washingtonpost.com/lifestyle/style/has-there-been-anobama-effect-in-hollywood/2016/09/01/1c3b1e76-62f1-11e6-8b27bb8ba39497a2_story.html Retrieved 10 Dec 2019.

"How Harvey Milk Changed the Gay Rights Movement". Youtube, uploaded by Filim Radar, 
28 April 2018, https://youtu.be/69xLk1nn5z4 Obtained 28 Feb 2020.

Joon-ho, Bong. "Parasite". Barunson E\&A, 21 May 2019.

Karizat, Nadia. " One College Student's Analysis on Representation in the Film American Sniper". Huffpost, 26 April 2015, https://www.huffpost.com/entry/one-collegestudents-anal_b_7424352. Accessed 26 Jan 2020.

Keith Negley, Keith. "The Hashtag That Changed the Oscars: An Oral History". The $\begin{array}{lllll}\text { Newyork } & \text { Times, } & 06 & \text { Feb } & \text { 2020, }\end{array}$ https://www.nytimes.com/2020/02/06/movies/oscarssowhite-history.html Retrieved 15 Mar 2020.

Kelly, E. Robert. " The 'Hurt Locker' Should Not Be Best Picture ". Asian Security Blog, 07 Mar 2010, https://asiansecurityblog.wordpress.com/2010/03/07/the-hurt-lockershould-not-be-best- picture/ . Accessed 15 Nov 2019.

Knight, Travis. "Kubo and the Two Strings". Laika, 13 Aug 2016.

Makarechi, Kia. "'The Obama Effect': Harvey Weinstein Explains Why More AfricanAmerican Movies Are Being Made". Huffpost, 10 Sep 2013, https://www.huffpost.com/entry/obama-effect-harvey-weinstein_n_3900193 Retrieved 17 March 2020.

Mandrell,Andrea. "'12 Years' captures brutality, reality of slavery". USA Today, 17 Oct 2013, https://amp.usatoday.com/amp/2995965 . Accessed 14 Feb 2020.

Melfi, Theodore. "Hidden Figures".Fox 2000 Pictures, 10 Dec 2016.

Palczewski, Catherine. "Django Unchained and the Undisturbed Frontier Hero Archetype". Taylor and Francis Journals, $30 \quad$ Jan https://www.taylorfrancis.com/books/e/9781315763965/chapters/10.4324/978131576 396 5-23 .Retrieved 21 Mar 2020.

Pan, Daniel. "Moonlight — symbols, motifs and its message". Medium, 24 June 2019, 
https://medium.com/@danielgnpan/moonlight-symbols-motifs-and-its-message8f8d3111 8a6f . Retrieved 20 Feb 2020.

Ramirez-Valles, Jesus. "Queer Aging: The Gayby Boomers and a New Frontier for Gerontology". Oxford University Press,15 Aug 2016.

Ready, James. Tyler. " Trolling Islam In American Sniper ". Scholarworks, 2017, https://scholarworks.montana.edu . Accessed 11 Nov 2019.

Sangweni, Yolanda. " The Way-Too-Short List Of Black Oscar Winners ". Essence, 24 Feb 2019, https://www.essence.com/celebrity/way-too-short-list-black-oscar-winners/ . Accessed 20 March 2020.

Spielberg, Steven. "War Horse". Touchstone Pictures, 25 Dec 2011.

Tasker, Yvonne. Eylem, Atakav. " The Hurt Locker : Male Intimacy, Violence and The Iraq War Movie ". Sinecine, 2010, https://sinecinedergi.org . Accessed 27 Jan 2020.

Taylor, Tate. " The Help". DreamWorks Pictures, 9 Aug 2011.

Tyldum, Morten. "The Imitation Game". Black Bear Pictures, 29 Aug 2014.

"What is Hegemony? Antonio Gramsci and the Prison Notebooks". Youtube, uploaded by University Quick Course, 22 Sep 2018, https://youtu.be/RFQrV8UxpVA Obtained 26 Feb 2020.

Vallée, Jean-Marc. "Dallas Buyers Club". Truth Entertainment, 7 Sep 2013. Walker, Jesse. "The Elusive Politics of American Sniper". Reason, 2 Feb 2015, https://reason.com/2015/02/20/elusive-politics-of-american-sniper/?amp\#referrer= https://www.google.com .Accessed 11 Nov 2019.

Washington, Denzel. "Fences".Bron Creative, 15 Dec 2016.

" What is Queer Theory?". Youtube, uploaded by Kelsey Forman, 30 July 2018, https://youtu.be/E7p1c2ofLIU Obtained 26 Feb 2020 